\title{
Physical therapies in 19th century Aotearoa/New Zealand: Part 1 - Māori physical therapies
}

David A. Nicholls GradDip, MA, PhD Associate Head (North), School of Public Health and Psychosocial Studies, Auckland University of Technology

Grayson Harwood BHSC (Physiotherapy), BSC (Anatomy and Structural Biology) Physiotherapist, Cross Physiotherapy and Pilates

Ricky Bell MManipPhty (Distinction), PGDipMPhysio (Distinction), BPhty (QId), MPNZ, Centre for Health, Activity, and Rehabilitation Research (CHARR), School of Physiotherapy, University of Otago

\section{ABSTRACT}

This paper is the first of three reporting on a historiographic study of physical therapies in 19th century Aotearoa/New Zealand. This first paper focuses on traditional Māori healing practices. The paper begins by setting out the parameters for the study and outlining the role that massage and manipulation, electrotherapy, hydrotherapy and remedial exercise played in societies around the world prior to the 20th century. We then explore traditional Māori physical therapies, focusing on two broadly 'orthopaedic' conditions (fractures and back pain), before examining accounts of two predominant forms of physical therapy: massage and the use of Aotearoa/New Zealand's abundant thermal springs. We conclude the paper by examining the cultural shift that took place with colonisation after 1840, and consider the effect that this shift had on Māori physical therapy practices prior to 1900.

Nicholls D, Harwood G, Bell R (2016) Physical therapies in 19th century Aotearoa/New Zealand: Part 1 - Māori physical therapies. New Zealand Journal of Physiotherapy 44(2): 75-83. doi: 10.15619/NZJPI44.2.02.

Key words: Māori, Tohunga, Massage, Bathing, Physical Therapy, Fractures, Back Pain, Colonisation

$\ldots \ldots \ldots \ldots \ldots \ldots \ldots \ldots \ldots \ldots \ldots \ldots \ldots \ldots \ldots \ldots \ldots \ldots \ldots \ldots \ldots \ldots \ldots \ldots \ldots \ldots \ldots \ldots \ldots \ldots \ldots \ldots \ldots \ldots \ldots \ldots \ldots \ldots \ldots$

\section{INTRODUCTION}

This paper reports on a study undertaken to examine why it appears that the physical therapies (massage and manipulation, electrotherapy, hydrotherapy and remedial exercise) were some of the most popular therapies in Europe and North America during the $19^{\text {th }}$ century, but were almost completely absent from Aotearoa/New Zealand culture before 1900. In the paper, we detail the background to the study and outline a detailed historiographic account of existing texts, which show that there is some evidence of physical therapies being used by Māori prior to and during the $19^{\text {th }}$ century. Subsequent papers will explore the practices of colonial settlers and argue that the particular nature of colonisation in New Zealand failed to create the conditions in which the physical therapies could flourish. We conclude these papers by arguing that although a few practitioners did establish themselves before 1900, accounts of their activities are incidental and piecemeal.

The origins of this study lie in five intersecting conditions. Firstly, physiotherapy in New Zealand celebrated its centenary in 2013, and the profession represents one manifestation of the physical therapies in an organised, disciplinary form. But this organisation only began in 1913, and in undertaking research into the profession's early history it appeared that there were few physical therapy practitioners in New Zealand prior to 1900. Secondly, a great deal of data exists indicating that the physical therapies were extremely popular and widely used in Europe and North America during the 19th century. And so thirdly, we assumed that many of the colonists who arrived in New Zealand from Australia, Europe and North America in the $19^{\text {th }}$ century would have known about or been exposed to at least some of these therapies, and some may well have been practitioners themselves. Fourthly, we were aware that Māori used physical therapies as part of Indigenous healing practices, but that published accounts of massage and the use of thermal springs were limited. Finally, despite much of the development work taking place in the last two decades of the $19^{\text {th }}$ century, the largest organised centre for the development of the physical therapies in New Zealand prior to 1913 - Rotorua Spa - did not become established until after 1901 with the creation of the world's first Department of Tourist and Health Resorts.

Given these five conditions, we asked what evidence existed for physical therapies in New Zealand; to what extent were they practised; by whom, where and when. The study used historiographic methods to identify and review texts from a wide range of primary and secondary sources, including published and unpublished manuscripts, period newspapers, personal accounts, photographs, registers and directories, available either online, through databases like Papers Past, or with first hand archival searching at Archives New Zealand, the Alexander Turnbull Library and the National Library. ${ }^{1}$ Secondary texts were also examined for accounts of physical therapies and evidence of interest in the subject. Before presenting the findings of the study, we will unpack some of the context underpinning the

\footnotetext{
All of the texts examined in this study were in the form of written documents. These inevitably privilege 'western' modes of historiographic recording. No primary oral accounts of Māori healing practices were identified, although some of these are reported by Pakeha in their own accounts of 19th century practices.
} 
study and explain in more detail how the texts were identified and read.

\section{BACKGROUND}

Physical therapies were some of the most popular and widely used therapeutic remedies in Europe and North America in the $19^{\text {th }}$ century. Prior to the discovery of germ theory in the 1880s, pharmaceutical and surgical interventions were both potent and risky, with doctors actively engaged in 'heroic medicine,' in which their remedies were deliberately designed to be more arresting than the disease. Doctors regularly used blood-letting, purging and blistering, aggressive and unnecessary surgeries, and prescribed poisons such as arsenic and calomel (a mercury salt) to treat everything from acute fevers, chronic diseases and diarrhoea to teething pains (Wilson 1998, pp. 16-17). More conservative therapies like massage and bathing were therefore popular, not least because they were less draconian.

Among the many manual therapies practised in the $19^{\text {th }}$ century, which included bone setting and manipulation, massage had achieved particular prominence, not least as an expression of luxury and status, as increasing urban wealth gave birth to the idea of leisure industries focused on the body. Variously qualified massage practitioners began to advertise their services in all major cities across Europe and North America, and massage became a new and appealing career choice for educated young women. Nurses and midwives received special training in massage, allowing them to diversify their practice to incorporate therapeutic as well as caring capabilities. Independent practitioners worked from practice 'rooms' or visited wealthy clients in their own homes. But perhaps because of its popularity and association with sensual touch, massage began to acquire an unsavoury reputation in the 1880s, and by the mid-1890s had begun to create scandal, as poorly trained masseurs, brothels and bagnios came to the attention of Victorian civic reformers. As a result, massage began to be formally organised and regulated after 1900 in many western states.

Electrotherapy was, perhaps, even more popular than massage as a therapeutic remedy in the $19^{\text {th }}$ century. After the development of the electric battery by Galvani and Volta in the late 1800s, and the realisation that electrical charge could be applied to animate the human body, the possibility that weak, fatigued or ailing bodies could be 'galvanised' became a reality. Electricity entered the popular imagination, and people believed that the vital powers of electrical energy could raise the dead or be used to create life from inanimate tissue. ${ }^{2}$ Galvanism and faradism became the mainstay of therapies for some of the most prevalent 'nervous' conditions known in the $19^{\text {th }}$ century, including hysteria, neurasthenia and hypochondria, and a number of electrical consumer products were developed to 'recharge' people's ailing constitutions.

Hydrotherapy and balneotherapy, including bathing, steaming and drinking spa water, were known colloquially as 'taking

\footnotetext{
2 See, for example, Mary Shelley's Frankenstein, originally published in 1831.
}

the waters,' became significant industries in the $19^{\text {th }}$ century and gave birth to the development of spa centres and entire towns devoted to hydropathic tourism. Spa centres in America, Austria, England, France, Germany, India, Japan, Romania, and South America became resorts, frequented by some of the first leisure tourists, and a vast array of remedies began to emerge, with each centre promoting the specific chemical composition of the waters and innovative modes of delivery. Spa therapies connected the Victorian romantic passion for the power and mystery of nature with the technological innovations that arose after the Industrial Revolution, and provided a way for wealthy leisure travellers to escape the pressures of urban living. The development of railways and inter-continental travel made spa centres much more accessible and increasingly popular as the century progressed.

Remedial exercise and gymnastics. Physical fitness had been recognised for many centuries, dating back to at least GrecoRoman 'gymnasia,' but physical conditioning became a major concern in the $19^{\text {th }}$ century through the work of Pehr Henrik Ling (1776-1839) and the Royal Central Institute of Gymnastics in Stockholm. Ling trained doctors in a regime of educational and remedial gymnastics that would be exported throughout Europe and influence the physical culture movement in America and elsewhere. Physical culture itself was a powerful response to nationalistic fears of racial degeneration that began to emerge after Darwin's On the Origin of Species was published in 1859, alongside the racial pressures caused by incessant national wars, industrialisation, colonisation and migration. Physical exercise moved from being a pastime to a regime that could be used to develop the strength of children, improve one's health, and facilitate convalescence and recovery from incapacity. Physicians like Jonas Zander (1835-1920) in Sweden and John Harvey Kellogg (1852-1943) in the United States would have a profound effect in shaping the popularity and utility of exercise in the $19^{\text {th }}$ and early $20^{\text {th }}$ centuries.

\section{THE NEW ZEALAND CONTEXT}

It was known that some physical therapists existed in New Zealand prior to 1900 , because in undertaking research for the physiotherapy profession's centenary in 2013 we had come across people like Matthew Guinan, John Jenkins and Edwin Booth, who had all practised in the 1890s. We also knew that Māori healing practices included many forms of physical therapy. But accounts of the physical therapies in the published medical histories of the period made scant reference to any specific practices. L. K. Gluckman's Tangiwai and T. M. Hocken's Bibliography of the literature relating to New Zealand, for example, make no mention of any physical therapies (Gluckman 1976, Hocken 1909). There are accounts of institutions where physical therapies may have been taught, like Carmalt Jones's Annals of the University of Otago Medical School (Carmalt Jones 1945), and places where physical therapists may have been employed (Angus 1984, Williams 2010). Equally there are histories of allied health professions that were known to have either deployed physical therapies, or worked alongside therapists (Maclean 1932, Smillie 2003, Wilson 1998), but in all cases there are few if any specific references to the practices of the physical therapies, or its practitioners. 
The same picture can be seen in some of the specific local histories of health events that one would assume to be amenable to physical therapy practice (Bryder 1996); in general relevant histories of New Zealand in the $19^{\text {th }}$ century (Olssen and Stenson 1989, Werry 2011); and in accounts of injurious or regrettable lifestyles led by colonists, prospectors and settlers (Eldred-Grigg 2008). Historical accounts of the thermal springs so highly prized by Māori and colonial settlers focus heavily on the location and configuration of thermal pools (Petty et al 1987, Rockel 1986), and when centres of physical therapy practice are mentioned, as in the history of Rotorua Spa, the focus is on the socio-political machinations and significance of the centre, not on the therapists who undertook the day-to-day work of the spa (Bassett 1998, Loader 2012, McLure 2004). Indeed, the physical therapies are almost entirely absent from most of these accounts.

In Eldred-Grigg's account of life in the gold rushes of the 1860s, for example, we are provided with a picture of unremitting debauchery, disease and squalor, as well as regular death and physical injury, among the communities of transient prospectors that mined the fields on the West Coast, Central Otago and the Coromandel. At no time, however, is it even suggested that a masseur, medical electrician, balneologist or other physical therapist may have been operating among communities that effectively functioned as small towns. Nor is it evidenced that anyone received any kind of rehabilitative physical therapy as part of their recovery from the recurrent amputations, head injuries, fractures and debilitating diseases. This is not to say that physical therapies were not provided, only that, until now, the question has not been deemed interesting enough to warrant scholarly attention.

A similar picture emerges in the literature on colonial relations (Moon 1993, 2009), settler lifestyles (Macgregor 1973), and urban development (Fairburn 2013) in New Zealand during the $19^{\text {th }}$ century. It may be, of course, that the physical therapies were almost entirely irrelevant in large parts of New Zealand, where the struggle to survive and cope with isolation or grinding poverty were more significant considerations than massages and spa baths. Certainly Eldred-Grigg provides a paradigm case for such an argument;

When Isaac McCulloch fell sick with 'brain fever' he was carried by his mates overland for several days from Gabriel's Gully. A digger who twisted his leg on the Waipōri diggings was carried by his mates for three days...A 'powerfully built young fellow' whose ankle was smashed at Kaniere was carried by his mates in a litter to Hōkotika, where he in turn spent months nursing a 'young frail lad' dying of tuberculosis (Eldred-Grigg 2008, p. 257).

Accounts of this sort suggest that the physical therapies were a luxury to many living in colonial New Zealand. But to establish the evidence to support such a claim, it was necessary to undertake an exhaustive search of existing texts pertaining to health care in $19^{\text {th }}$ century New Zealand, and establish exactly what evidence existed for the argument that the physical therapies were largely ignored as therapeutic interventions, despite evidence of their significant popularity in Europe and North America at the time. What follows is an outline of the methodology used to identify relevant texts.

\section{METHODOLOGY}

The project to retrieve archival texts centred on two principal 'locations': an online database and a physical search of national libraries and archives. The online database used was Papers Past, a catalogue of over 120 full text, digitised New Zealand newspapers, dating back to 1839 . The physical search centred on Archives New Zealand, Alexander Turnbull Library, and the National Library located in Wellington, New Zealand. The majority of the search was undertaken between September 2014 and March 2015, and the archival work was undertaken entirely by the paper's authors. An initial data trawl was conducted using massage, hydrotherapy, electrotherapy and therapeutic exercise as key words, with the relevant time period set at 1800-1899. Relevant texts were selected and closely read to draw out appropriate key words which were used to form an expanded search strategy. A refined search was then undertaken based on parameters set out in Table 1 below.

Table 1: Primary and secondary data sources

Media Named source

Newspapers

Ashburton Guardian, Auckland Star, Bay of Plenty Times, Bruce Herald, Bush Advocate, Clutha Leader, Colonist, Daily Southern Cross, Daily Telegraph, Ellesmere Guardian, Evening Post, Feilding Star, Grey River Argus, Hawera and Normanby Star, Hawke's Bay Herald, Hot Lakes Chronicle, Inangahua Times, Lake Wakatipu Mail, Manawatu Herald, Marlborough Express, Mataura Ensign, Mount Ida Chronicle, Nelson Evening Mail, New Zealand Herald, New Zealander, North Otago Times, Northern Advocate, Oamaru Mail, Observer, Ohinemuri Gazette, Otago Daily Times, Otago Witness, Poverty Bay Herald, Press, Southland Times, Star, Taranaki Herald, Te Aroha News, Thames Advertiser, Thames Star, Timaru Herald, Tuapeka Times, Waikato Times, Wairarapa Daily Times, Wanganui Chronicle, Wanganui Herald, West Coast Times.

Published and unpublished manuscripts

Photographs

Directories

Secondary texts
Personal accounts, government legislation, correspondence with Ministry, correspondence to family, medical registers.

Tourist Department Album, regional photo archive, subject photo archive.

Post office, trades, and medical directories.

Medical history, 19th century NZ history, major hospital histories, Maori history, medical and nursing history, guides, thermal springs and sanatorium history, NZ regional history. 
Online searching was conducted methodically, using a range of refined Boolean search parameters, including: balneo*, exercis*, hauwai, waiariki, ngawha, masseu*, mirimiri, "Swedish movement cure," gymnastics AND correct*, electrotherap*, health AND physical, "hot springs". Search results were individually scrutinised and collated into a catalogue, indicating the relevance of each of the findings (see Figure 1 below for an example of the catalogue reporting structure.)

\section{PP[balneo*] [1 Jan 1880-31 Dec 1889] [articles only]: 9 results}

- Star, 30 July 1880, Local and General - Describes a 'balneological exhibition' happening in Germany

- Wararapa Daily Times, 7 January; Auckland Star, 7 January; Otago Daily Times, 31 December 1880 Mentions the exhibition in Germany and asks why New Zealand isn't represented there

- Mount Ida Chronicle, 30 September; 2 October 1886, Miscellany - Mentions the treatment of obesity including diet, exercise and balneotherapy (or bathing)

- Waikato Times, 9 February 1884, Syndey Sketches Mentions 'Koumiss,' a dietetic and hygiene remedy written about in the Journal of Balneology

- 2 errors

Figure 1. Catalogued findings from Papers Past archive search

Each catalogue item was then read and organised into a thematic archive organised around events, geographical locations, and named individuals or groups. Key moments of significance, including analyses, arguments, images, policies and statements, were highlighted and cross-referenced across the archive. The archive could then be synthesised and reported.

\section{FINDINGS}

Physical therapies in $19^{\text {th }}$ century New Zealand can be broadly understood in two distinct, yet significantly overlapping categories: traditional Māori healing, and post-colonial practices. Traditional Māori practices were those that existed prior to colonisation, a point formally recognised by the signing of New Zealand's founding document Te Tiriti o Waitangi or The Treaty of Waitangi in 1840. These practices continued after the signing of Te Tiriti, but suffered with the decline of the Māori population and attempts by various governments to outlaw the practices of tohunga. ${ }^{3}$ Post-colonial practices were introduced by early settlers, with many thousands of immigrants arriving from Europe (mainly England and Scotland), the United States and Australia.

\footnotetext{
3 Tohunga refer to healers, educators, and tribal leaders who possessed special connections with ancestors and knowledge of plant lore, healing and educational practices. Tohunga held similar social status to doctors in western society but had a wider range of skills and responsibilities. Tohunga were the guardians of Māori traditional healing practices and attempts to outlaw their practices converged in the 1907 Tohunga Suppression Act.
}

As with many Indigenous healing practices, Māori physical therapies included beliefs, customs and rituals that differed significantly from the practice conventions western doctors began to actively construct in the $19^{\text {th }}$ century. Māori physical therapies cannot be seen in isolation from other therapeutic practices, including the tohunga's invocation of atua (or gods/ spirits); customary practices, like the isolation of the injured (or tapu) person, from the rest of the tribe; or the use of plant matter for practices like massage, steaming, and splinting. The flax bush, for example, would be cut to make matting, bandaging, and mobile splinting. But at no stage would the flax be cut or used without an appropriate appeal to atua. W. M. Goldie, for example, states that Māori invoked the god Maru to 'descend upon the crown of the head (the most sacred part of the body) of the injured person, and apply his healing power to the wound or the injured limb' while repeating an ancient karakia [incantation] originally used to 'raise Rakei from the dead' (Goldie 1903, p. 58). The tohunga's role was to mediate between the spirit world and the injured person, and the various therapies available to tohunga were learnt through years of contemplation, korero [conversations] and spiritual practices (Riley 1994).

By contrast, $19^{\text {th }}$ century medicine was developing the reductionism that would lead to the creation of medical specialties (orthopaedics, neurology, respiratory, etc.), and the separation between different practical modalities (massage, hydrotherapy, pharmacopoeia, etc.) (Nicholls and Gibson 2010, Turner 2008). Reflecting the colonial influence on Māori healing practices over the $19^{\text {th }}$ century, we have retained these organising principles and structures in structuring this paper. Thus we will illustrate two of the main therapeutic approaches (massage and bathing), and two of the main 'orthopaedic' insults: back pain and fractures, to reflect the gradual supplanting of Māori cultural practices with western medical approaches during the century. It should be noted, however, that fractures and back pain, massage and bathing, were only small constituents in the vast sweep of health problems and practices seen in $19^{\text {th }}$ century Mãori health, and as an organising structure it pays little heed to the extensive use of plant materials and spiritual practices that were so important to the holistic and integrated approach to healing offered by the tohunga.

\section{Back pain / Tuarā mamae}

Back pain was probably very common among Māori. G. S. Cooper, travelling from Auckland to Taranaki with Māori porters in $1849 / 50$, recounts that;

The natives all complained very much of pains in the backs and legs from the weight of their loads, some of which were undoubtedly very heavy; their mode of curing these pains was by lighting enormous fires and placing the aching part as close as possible to the heat, this they said had the effect of relaxing the muscles and rendering them fit for service on the following day (Cooper 1851, p. 32).

Philip Houghton's examination of pre-European skeletal remains showed that cervical and lumbar degeneration was common even in young adults (Houghton 1980). Houghton followed William Colenso in speculating that this may have been caused 
by heavy canoeing, particularly powerful stroke angles; carrying heavy loads; and the heavy labour involved in kumara and fern root cultivation and excavation (Colenso 1869). The treatment for back pain included the use of heat for relaxation, massage and bracing. J. White (White n.d.) provides one account of this treatment:

If the back is sore from lifting or is simply giving pain, the patient goes to the water (river) and sits, whereby he is massaged by the tohunga using his hands. The patient then returns to stand beside the fire, with his back to the fire. He then returns to the tohunga, who again massages the painful area. The patient then returns to the fireside to bask in the heat, the whole process being repeated two, three or four times, and then the painful area is strapped with a woven flax belt and left like that till the back is healed (n.d.).

The tohunga would deploy a range of massage techniques and lubricants (see below), including the use of heated stones, but extreme care was needed here, because although '[p]ressure on the body by placing heavy bags of stones or earth was said to cure disease by squeezing out the evil spirit...the method sometimes proved fatal' (Thomson 1859, p. 141).

\section{Fractures / Wheua whati or Poroiwi whati}

Prior to colonisation and the arrival of munitions into New Zealand, it is likely that fractures among Māori were rare. But Houghton's osteoarchaeological research suggests that they were frequent enough to provide evidence of well developed healing skills (Houghton 1980). Riley argues that '[u]ndoubtedly [Māori] knew what they were doing when it came to fractures' (Riley 1994, p. 59). Dr. Tuke also notes that 'the results bear excellent comparison with the cures effected by bone-setters in our own country [England]' (Tuke 1863).

The methods used for treating fractures included isolating the injured person from the rest of the tribe, bathing the fracture site in steam and, when relaxed, reducing and splinting the limb. The whole procedure would be accompanied by specific incantations, or hono (meaning 'to join'), performed by the tohunga (Goldie 1903):

If a person has broken, fractured or chipped a bone, he is taken from the village to a place away from where people sleep. A sacred fire is lit and the tohunga performs a ritual. Stones are not allowed by this fire ??? but the koromiko, the whau (possibly the cork tree, Entelea arborescens), and the karamū (Coprosma spp.) are broken off, taken to the water, wetted, and while the fire is burning well the wet branches are thrown over it. These are then placed over the wound??? so that the whole area of the wound is steamed. This is to soothe the flesh around the area of the break. If this does not have the desired effect at the first steaming, then another is done and more fires have to be lit. When the wound is being steamed that is the time to re-set the bone so that everything is in place as before. When the bones are re-set the area is kept heated and a splint made. The splints, one on top and one on the bottom, are tied firmly together with flax. All this is closely observed by the tohunga. When the wound is healed the whole tribe feasts on the marae (the Māori meeting house) (Riley 1994 p13).
Back pain and fractures represent just two of the many conditions treated by Māori using physical therapies. Arthritis or mate kaikōiwi, ${ }^{4}$ asthma, bronchitis, burns, headaches, neuralgia, sprains, strains and wounds, as well as evidence of a full range of medical conditions, including cancer, diabetes and tuberculosis were also treated (Riley 1994). Massage and steam bathing appear to have been the predominant physical therapies used, or at least those cited by $19^{\text {th }}$ century colonial travellers. In comparison with their colonial counterparts, there is no evidence of any access to electrical modalities, and no evidence of well known Māori occupations and activities that might have been used therapeutically, including kapa haka (traditional dance) or waka ama (outrigger canoe racing); occupational activities like tinana waka/marae (building and restoring boats/meeting houses) or flax weaving; hikoi (walks); or warrior training 'games' like poi rākau (long staff) or patu (short handled club).

\section{Massage}

The main types of massage utilised by Māori included tōtō, romiromi, takahi, mirimiri and tukituki. These terms referred to the method of application, but in some cases they also described the relationship between the practitioner and their subject.

\section{Tōtō}

Tōtō involved the gentle, general massaging of children, using stroking and rubbing movements akin to effleurage. It was performed on infants and children by the women of the tribe, and was considered a vital part of the child's development. Maggie Papakura (Makareti) recounts in 1938 that Māori children were massaged from birth and wrapped in a pūera (cloak) to ensure they developed a strong, straight back (Makareti 1938). ${ }^{5}$ Infants were massaged each day to develop their comportment. Elsdon Best, one of New Zealand's earliest anthropologists, noted that:

If ears projected, they were pressed in. If the legs were curved they were straightened. If toes spread out they were pressed in. A projecting heel pressed. Bowed shoulders pressed back to straighten them and make the chest prominent. The process continued for weeks (Best n.d.).

Numerous observations pointed to the widespread use of tōtō and other manipulations performed on children to develop their physical form: Colenso described the massage of the nose and forehead, supposedly performed to make hongi (nose pressing as greeting) easier (1869); Tregear and Makareti described approaches designed to produce slightly bowed legs - a form 'much admired' by Māori (Makareti, 1938, Tregear 1904). Riley states that:

[c]hildren were bathed in cold water and slapped vigorously with the partly clenched hand and knuckles to make the flesh firm. Female infants had the first joint of their thumbs half disjointed or bent backwards so that when they were older they could more easily prepare and weave flax. Male

\footnotetext{
4 Mate kaikōiwi literally translates as 'death by bone.'

${ }^{5}$ Dr Tuke in 1863 reported that spinal malformations were rare among Māori (Tuke 1863).
} 
children were massaged so they would have a good physique to fight, do war dances etc. when they grew up (Riley 1994, pp. 73-4).

\section{Romiromi}

Romiromi also refers to a general massage, but one performed on adults akin to petrissage, involving repetitive squeezing and compression of soft tissues. White reports that 'Romiromi was carried out each night at sunset before the evening meal, always at the same time. The fleshy parts of the patient's body were gently squeezed or pinched, the legs, arms and back getting specially rubbed' (White 1883).

\section{Takahi}

Takahi refers to a vigorous form of massage in which the masseur 'tramples' barefoot on the patient. In some tribes takahi was performed by someone who carried the special significance of being born feet first. This person was known as whānau weawae (meaning literally 'bare feet') (Buck 1910). Takahi would normally be accompanied by oiling of the body and steam bathing, in the manner described here by White;

The patient would make a couch of grass or mats, as long as the body, and then lie down on it with the stomach to the couch. The person acting as Doctor [sic] would stand on the patient's back and with his or her feet placed across the back, move each foot on the patient's back, commencing at the nape of the neck and treading with each foot downwards to the hips, moving each foot a little space onwards and following it with the other. Then after doing this up and down the patient's back a few times, the patient would go and sit in a steam bath for some time. Coming from that, the oil of miro would be rubbed in the back to cure what was called a "kope" (crack, twist or kink) of the back (White n.d.).

\section{Other methods}

Phillips reports that Māori practitioners would also use short strokes with fingers, called mirimiri, and tukituki, a technique using a pounding action of the fists, moving up and down the body (Phillipps 1973). Lubrication with pigeon fat, whale oil, and the odourless fat from the lining of the intestines and stomach of a pig might also be used (Pōmare 1908, Rolleston 1989).

What we know of Māori massage practices in the $19^{\text {th }}$ century depends to a large extent on the veracity of accounts offered by travellers and anthropologists, since knowledge of Māori healing practices was conveyed orally by generations of tohunga and kaitiaki (tribal guardians). It is likely that practices would have changed during the century because of the dramatic increase in traumatic injuries that accompanied the introduction of munitions and heavy artillery after 1840. It is reasonably clear though, that massage performed by Māori bore many similarities to that undertaken by their European and North American counterparts: it was performed by someone with special responsibility and, in most cases, supervised training, and it was a major part of the $19^{\text {th }}$ century therapeutic armamentarium. There is also evidence that a gender role separation operated in both cultures. Wilson (1932) states that tohunga were always male, and there is some evidence of tohunga performing massage and tissue mobilisations on ill and injured patients, but Wilson reports that it was older women who were the chief massage practitioners (Wilson 1932). Elsdon Best also supports this role definition, stating that women learned massage by observing the way wahine kaumatua (women elders) massaged children each day (Best n.d.).

\section{Steam and water bathing}

In contrast with massage, bathing was a relatively passive therapeutic practice that required no intermediary. Evidence from settlers and travellers throughout the North and South Islands suggests that Māori made extensive use of thousands of naturally occurring mineral springs and pools for cooking, washing, relaxation and therapy. Indeed, Henry Morton recounted that 'To the natives, bathing is a 'cure for every ill, a salve for every wound' and whether it be a broken limb, a rheumatic pain, or any widely-different malady, they fly to the warm baths from all parts for relief' (Morton 1886, p. 23). Some thermal springs were considered highly prized for their physical beauty, their balance of hot and cold water, as places of ritual and ceremony, and as places of deep spiritual significance (Loader 2012).

Māori made therapeutic use of pools formed by waiariki (springs just hot enough to bathe in), ngawha (boiling spring forming pools into which cold spring water could be channelled or added), and mud baths. Steam was also utilised, either by placing the ill or injured person directly over a steam vent (protected by flax matting, herbs or branches of beneficial plants), or by fashioning a steam pit into which hot rocks, water and wet plant matter might be added, sometimes enclosing the patient within the pit for many hours.

Many of the accounts we have of Māori uses of water and steam bathing derive from the diaries and reports of $19^{\text {th }}$ century colonial travellers. People like J. T. Large, whoes 'Notes of a Trip to the Hot Lake District' were published in the Thames Advertiser in 1879:

After having partaken of a meal of boiled vegetables I went down to a famous waiariki to have a bath. This is situated on the large platform of silicious deposit, extending right down to the river, and in which there are many pot holes, some boiling, and others gently simmering, and others again of an intermittent character: one or two I noticed with a regular rise and fall at stated intervals; I had not been long immersed in my bath before I was joined by two young damsels from the pah [pā] above, who, nowise abashed by the presence of a stranger, entered readily into conversation about different things. We chatted, laughed, and foundered about and splashed one another till long after dark, and they freely confessed that I was the jolliest night companion of the bath they had ever met with. The bath was so luxurious and enjoyable that I felt inclined to remain there all night (Large 1879).

Luxury spas and the idea of 'taking the waters' had become a feature of leisure tourism in $18^{\text {th }}$ century Europe and North America, with spa centres developing wherever hot springs were found, so it is likely that many travellers saw the abundance of hot springs as further evidence that New Zealand was a place of natural wonder. The region in the North Island that was 
most geothermally active was called the 'Hot Lakes District' as a reflection of the English Lake District, and became the focal point for travellers through the country:

Early European visitors to the Lakes Thermal District included John Bidwill (1839), Ernst Dieffenbach (1841)... and Sir George Grey (1849), and several others. These men published accounts of their visits, describing the palliative and curative properties of the hot springs, the fabulous formations of the Pink and White Terraces on Lake Tarawera, geysers, mud pools and other attractions such as mixedgender bathing (Matthews and Matthews Architects Ltd, Stafford, Williams, Mercer, and Gainsford, 2007/2010).

One such traveller, Dr John Johnson, first colonial surgeon and physician to Governor William Hobson during his illness and subsequent stroke (Moon 1998), travelled through New Zealand recording his observations. His account of his arrival in Rotorua reflects the wonder expressed by many:

Continuing our course parallel to the shores of the lake, we came to a pool, from which vapour was rising, and on immersing our hands, found it to be of a temperature from which we quickly withdrew them. This then was our first acquaintance with the boiling springs of Rotorua, and we had now fairly entered upon this extraordinary region (Johnson 1847a).

After a night's sleep, Johnson recounts his first experience of bathing in the hot lakes;

We rose at day-break, and on going out found the whole $\mathrm{pa}^{6}$ enveloped in vapour, which was rising from the numerous Ngawha [sic], and we could hear the voices and the splashing, though we could not see the persons, of a number of people in the lake below, who were enjoying the luxury of a bath, in the common bathing-place... On reaching the edge of the basin, a scene, certainly unique of its kind, presented itself. About a hundred and fifty people of all ages were engaged in bathing, all in a state of nature, with the exception of the women, who, beyond a certain age, wore the bouraki, a species of kilt made of flax, reaching from the waist to the knee. In one corner might be seen a group of young women with dripping tresses, like so many Stygian Naiads, ${ }^{7}$ in another, a swarm of young urchins, sporting about like so many imps in Dante's Inferno (Johnson 1847b).

Johnson reported that many local Māori spent 'half their time' bathing (ibid) and speculated that although this might be therapeutic and beneficial to the skin, it may also be the cause of disease, resulting in children 'disfigured by glandular swellings about the neck, and other scrofulous tumours' (ibid). Johnson speculated that the acidity was the cause of the inhabitants' blackened and decayed teeth, and that imbibing

\footnotetext{
6 A Māori pah (or more correctly pā) site is a promentory used for settlement (sometimes defensive) akin to a hill fort.

7 In Greek mythology, the Naiads were water nymphs or female spirits who presided over fountains, wells, springs, streams, brooks and other bodies of fresh water. Stygian here refers to the mythical River Styx.
}

the water caused Europeans, who were unused to it, to develop indigestion and 'irregularities of the bowels' (ibid).

\section{Hot springs were one of the principal modes of health} promotion and recovery for Māori, with travellers like William Wade recounting in 1842 that 'the springs at this place [the Bay of Islands] are much resorted to by diseased natives... who bring baskets of provisions with them, and remain on the spot to use the sulphur warm-bath till a cure is effected' (Wade 1842). John Johnson concurred, claiming that the thermal springs and pools '....possess valuable medicinal qualities both for internal use, and external application, as the Natives [sic] cure many diseases by simple immersion in them, but I should imagine that their uniform heat is the most active agent in the cure' (Johnson 1847b). Johnson believed like many of his counterparts though, that 'an accurate analysis of their individual composition... would throw light on their use in specific diseases, and it would be desirable that such should be made under the auspices of Government' (ibid).

Māori also used a variety of methods to generate steam for therapeutic purposes, or to utilise naturally occurring steam. Umu (baking a steam bath over heated stones or a small oven), and umuroa (steaming in a full earth oven), were both common. Dr. Arthur Thomson described the way an umuroa functioned after travelling through New Zealand in 1854-5:

The vapour bath is made by digging a hole in the ground about two feet deep, and as large as is required: into this a number of very hot stones, about the size of a large orange, are put, a quantity of water is sprinkled over the stones, and over them a thick bed of the leaves of the plants which are supposed to be efficacious in the cure of the disease are spread. The patient either lies down on them, or sits on them...the body is covered with a mat and a layer of earth... the steam generated by the water on the hot stones rises through the leaves, envelopes the body, and produces a copious perspiration. This bath is often given; sometimes the patients are kept in it from sunrise to sunset, but generally for two or three hours' (Thomson 1855).

Riley reports that umuroa were observed by the crew of Captain Cook's ship Endeavour on its first exploration of New Zealand in 1769, when 'stones [were] being heated and green celery placed on them. An old woman then seated herself on a mat over the steam rising from the celery placed on them' (Riley 1994, p. 22). Another method, huahua, involved bathing in water that had been heated in a container into which hot stones had been thrown. Commonly herbs, tree barks and seaweed would be added to the water to effect a particular cure (Macdonald 1973).

\section{DISCUSSION}

The purpose of this paper was to present the first organised account of physical therapies among tangata whenua (Indigenous peoples of the land) in $19^{\text {th }}$ century New Zealand, before organised health professionals colonised the physical therapies and turned them into state-supported occupations. One cannot provide such an account, however, without also considering the practical, day-to-day changes that were brought about during a century of colonisation. This is perhaps 
particularly relevant when we consider the thermal springs that were a significant feature of Māori daily life in some parts of New Zealand, because these springs represented a powerful physical, spiritual and cultural asset that was much coveted by the colonists.

Interest in the thermal springs was such that measures were taken in 1881 to cede control of ngawha, waiariki, lakes, rivers, and bodies of water under the auspices of the Thermal Springs Act and effectively remove governance of the land from Māori. According to the Bay of Plenty Times, the Act:

....put an end to the chronic disputes that have arisen between Europeans that were enterprising enough to risk their money upon the mere promises and good will of the native owners in order to make some provision for the accommodation of visitors ("Thermal Springs Act 1881," 1881).

The Act made it unlawful for anyone other than 'Her Majesty to acquire any estate or interest in native land therein' (ibid), and gave the colonial government powers to 'Manage and control the use of all mineral springs, hot springs, ngawha, waiariki, lakes, rivers, and waters, and fix and authorise the collection of fees for the use thereof.' The Act allowed representative authorities to '[e]rect pump-rooms, baths, bath-rooms, and other buildings for the convenient use of the baths, springs, and lakes' (Thermal Springs Act 1881). The Act was penned as hostilities between Māori and colonialists began to abate after the New Zealand Wars of the 1860s and safe leisure travel to New Zealand became a possibility. ${ }^{8}$ As such, the Act began a period of hostility towards Māori traditional healing practices that would be book-ended by a second piece of legislation called the Tohunga Suppression Act in 1907, whose sole purpose was to criminalise Māori Indigenous healing practices.

Much of the inspiration for the colonisation of Māori healing sites and practices lay in a desire to exploit the commercial potential of the thermal springs; a process that was only briefly interrupted by the eruption of Mount Tarawera and the destruction of the famous Pink and White Terraces on 10 June 1886. From the arrival of the first colonial travellers to the country's ngawha and waiariki in the 1830s, to the creation of the Rotorua Spa in 1908, an incremental wave of policies and practices, incursions and exclusions, moved Māori from their status as kaitiaki and tohunga, to one of exotic, Indigenous inhabitants in a colonised land.

The great irony of this action, of course, was that many of the physical therapies practiced by Māori were identical to those known to colonial settlers. The physical therapies, after all, had remained largely unchanged across cultures for many millennia, and so, clearly, the therapeutic practices themselves were not the focus of colonial interest, but rather the assets that provided the cultural context for their operation. In the following paper we will examine the way Māori healing arts were supplanted

\footnotetext{
8 The opening of the Suez Canal in 1869 not only boosted the tea trade with China, but also significantly shortened the sailing distance to Aotearoa/New Zealand.
}

by European and North American physical therapy practice culminating in creation of the 'spa town and ethnic tourism enclave of Rotorua' that 'was at once a wonderland and a hellhole' (Werry 2011). In the second paper we address why it was that so few physical therapy practices and practitioners came in to fill the void made possible by the marginalisation of traditional Māori physical therapies.

\section{CONCLUSION}

In this first paper of three looking at the history of the physical therapies in $19^{\text {th }}$ century New Zealand, we have concentrated on traditional Māori healing practices, most especially relating to the management of two 'orthopaedic' conditions: fractures and back pain; and two principal practices, massage and bathing in thermal waters. As stated above, this study has focused on Māori massage practices in the $19^{\text {th }}$ century using written accounts of travellers and anthropologists. The study did not focus on oral texts that would have furnished other accounts of Māori healing practices. We acknowledge that this limits the inclusiveness of the data. Our hope is to supplement this preliminary data with oral historical accounts in the near future. From the data we have presented, it appears that physical therapies used by Māori bore many similarities to those practised by most cultures prior to colonisation and the advent of modern medicine. New Zealand's geothermal resources afforded some tangata whenua particular privileges that would become the envy of colonial settlers, and result in the thermal springs becoming a feature of the colonisation project that began in earnest after 1840 . The effect of the annexation of land, the introduction of new communicable diseases, war and other mechanisms of colonisation, significantly affected the practices of physical therapies among Māori, and accounts suggest that although still practised, they became increasingly isolated events as the century wore on. In the following paper we discuss the very limited emergence of physical therapies among the settlers and the exceptional government-led project to create a spa town to attract a better class of invalid (Werry 2011), and kick-start a new era in health tourism at the end of the old century of conflict, and what was hoped to be the dawn of a new century of prosperity and cultural stability.

\section{KEY POINTS}

1. There is good evidence that Māori practised physical therapies long before colonisation and that these therapies were as successful as anything offered by colonial settlers at the time.

2. Physical therapies were performed by many members of the tribe, including tohunga, women, and whānau weawae all of whom would be trained to perform their particular techniques.

3. Māori use of physical therapies, along with other cultural assets, suffered as a result of colonisation, and reporting on the use of physical therapies by Māori declines after 1860 .

\section{DISCLOSURES}

This study was supported by an Auckland University of Technology Faculty of Health and Environmental Sciences Summer Research Award (CGHS 10/14). 


\section{ADDRESS FOR CORRESPONDENCE}

Associate Professor David A. Nicholls, A-11, School of Clinical Sciences, Faculty of Health and Environmental Sciences, Auckland University of Technology, Private Bag 92006,

Auckland 0627, New Zealand. Email: david.nicholls@aut.ac.nz. Telephone: $099219999 \times 7064$

\section{REFERENCES}

Angus J (1984) A History of the Otago Hospital Board and its Predecessors. Dunedin: Otago Hospital Board.

Bassett M (1998) The State in New Zealand, 1840-1984 Socialism Without Doctrines? Auckland, N.Z.: Auckland University Press.

Best E (n.d.) Māori Notebooks. qMS, 1885-1918, Alexander Turnbull Library, National Library of New Zealand.

Bryder L (1996) "A Health Resort for Consumptives": Tuberculosis and Immigration to New Zealand, 1880-1914. Medical History, 40(04), 453471. doi:10.1017/s002572730006169x.

Buck P (1910) Medicine amongst the Māoris in Ancient and Modern Times. Doctoral.

Carmalt Jones DW (1945) Annals of the University of Otago Medical School: 1875-1939. Wellington: A. H. and A. W. Reed.

Colenso W (1869) On the Botany of the North Island of New Zealand (Vol. 1). Wellington: New Zealand Institute.

Cooper GS (1851) Journal of an Expedition Overland from Auckland to Taranaki By Way of Rotorua, Taupo and West Coast in the Summer of 1849/50. Auckland: Williamson and Wilson.

Eldred-Grigg S (2008) Diggers, Hatters, and Whores: The Story of the New Zealand Gold Rushes. Auckland, N.Z.: Random House.

Fairburn M (2013) The Ideal Society and its Enemies: Foundations of Modern New Zealand Society, 1850-1900. New York: Auckland University Press.

Gluckman LK (1976) Tangiwai: A Medical History of 19th Century New Zealand. Auckland: Whitcoulls.

Goldie WM (1903) Māori Medical Lore. Christchurch: Kiwi Publishers

Hocken TM (1909) A Bibliography of the Literature Relating to New Zealand. Wellington: John Mackay.

Houghton P (1980) The First New Zealanders. Auckland: Hodder and Stoughton.

Johnson J (1847, November 17) John Johnson's Journals. New Zealander, p. 3 Johnson J (1847, November 20) John Johnson's Journals. New Zealander, p. 3

Large JT (1879, June 27) Notes of a Trip to the Hot Lakes District. Thames Advertiser, Vol XII, Issue 3352, p. 3

Loader F (2012) The Architecture of Pilgrimage: Sacred Sites and Sacred Self in the Quest for Meaning. Master of Architecture.

Macdonald C (1973) Medicines of the Māori. Auckland: Collins.

Macgregor MF (1973) Petticoat Pioneers; North Island Women of the Colonial Era. Wellington, A. H. and A. W. Reed.

Maclean H (1932) Nursing in New Zealand. Wellington: Tolan.

Makareti MP (1938) The Old-Time Māori. London: Victor Gollancz.

Matthews and Matthews Architects Ltd, Stafford D, Williams L, Mercer K, and Gainsford J (2010) Rotorua Central Area Built Heritage Study. Part one: Historical Summary. (Original work published 2007) Retrieved from www.rdc.govt.nz
McLure M (2004) The Wonder Country: Making New Zealand Tourism. Auckland: Auckland University Press.

Moon P (1993) An Introduction to Māori Economic and Social History to the End of the Nineteenth Century. Auckland: Huia Publishing in conjunction with Te Ara Poutama.

Moon P (1998) Hobson: Governor of New Zealand, 1840-1842. Auckland: David Ling Publishing.

Moon P (2009) The Edges of Empires: New Zealand in the Middle of the Nineteenth Century. Auckland, NZ: David Ling Pub.

Morton HM (1886) Notes on a Visit to the Lake District Sometime Between Nov. 1878 and June 1886. NZ MSS 683, Auckland Public Library.

Nicholls DA and Gibson BE (2010) The body and physiotherapy. Physiotherapy Theory and Practice, 26(8), 497-509. doi:10.3109/09593981003710316.

Olssen E and Stenson M (1989) A Century of Change: New Zealand, 18001900. Auckland, N.Z.: Longman Paul.

Petty DR, Homer DL and Brown LJ (1987) Mineral and Thermal Waters and springs of North Auckland. New Zealand Geological Survey.

Phillipps WJ (1973) Māori Life and Customs. Wellington: A. H. and A. W. Reed.

Pōmare M (1908) The Māori. Australian Medical Congress Transactions (October).

Riley M (1994) Māori Healing and Herbal. Paraparaumu: Viking Sevenseas.

Rockel I (1986) Taking the Waters: Early Spas in New Zealand. Wellington: Government Printing Office.

Rolleston S (1989) He kohikohinga: A Māori Health Knowledge Basis. Wellington: Te Wahanga Hauora Māori.

Smillie A (2003) The End of Tranquillity? An Exploration of Some Organisational and Societal Factors that Generated Discord Upon the Introduction of Trained Nurses into New Zealand Hospitals, 1885-1914. Master of Arts.

Thermal Springs Act 1881 (1881, September 15) Bay of Plenty Times, p. 2.

Thomson AS (1859) The Story of New Zealand. London: John Murray.

Thomson $\mathrm{H}$ (1855) On the Peculiarities in Figure, the Disfiguration, and the Customs of the New Zealanders. British and Foreign Medico-Chirurgical Review, 13-15.

Tregear E (1904) The Māori Race. Whanganui.

Tuke JB (1863) Medical Notes on New Zealand. Edinburgh Medical Journal, 9

Turner BS (2008) The Body and Society: Explorations in Social Theory. London: Sage.

Wade W (1842) A Journey in the Northern Island of New Zealand. Hobart: Rolwegan.

Werry M (2011) The Tourist State: Performing Leisure, Liberalism, and Race in New Zealand. Minneapolis: University of Minnesota Press.

White J (n.d.) MS papers. Alexander Turnbull Library, NLNZ. 75 B Series Misc. Notes.

White J (1883) Māori Pharmacopia. MS papers 75 B35/11, ATL, NLNZ.

Williams C (2010) Hokianga Health: The First Hundred Years - Te Rautau Tuatahi. Hokianga Health Enterprises Trust.

Wilson CA (1932) Legends and Mysteries of the Mãori. London: George G. Harrop and Co. Ltd

Wilson KF (1998) Angels in the Devil's Pit: Nursing in Rotorua, 1840-1940. Karo Press. 